\title{
Drone assessment of habitat selection and breeding success of Gull-billed Tern Gelochelidon nilotica nesting on low-accessibility sites: a case study
}

\author{
Francesco Scarton ${ }^{1 *}$, Roberto G. Valle ${ }^{2}$
}

\begin{abstract}
The use of drones in the study of waterbird breeding biology has received considerable attention in the last years, but very few studies were made along the Mediterranean. We studied habitat selection and breeding success of the Gull-billed Tern Gelochelidon nilotica in two colonies inside fish farms along the Italian Adriatic coastline, using a small, commercial drone. Both colonies were located on small islets surrounded by very shallow water and clayey bottoms, thus being difficult to access. Compared with availability, the Gull-billed Terns selected quadrats higher above the water level, with a higher vegetation cover, which lay farther from the water edge, contain less water, and which are more frequently located in the center of the islands. 147 of 178 clutches (mean clutch size \pm SD: $2.61 \pm 0.58$ ) hatched 383 chicks $(82.5 \% ; 2.15 \pm 1.09$ chicks per nest), with large differences between the two colonies. Hatching success was $95.0 \%$ and $69.1 \%$; the most common cause of egg loss was flooding $(97.0 \%)$. Nest attendance could easily be ascertained by $30-\mathrm{m}$ above ground level drone-derived imagery. The use of a drone allowed the study of some aspects of the breeding biology of the Gull Billed Tern in two breeding sites where the traditional field approach, i.e. researchers reaching the sites by boat, would have been very difficult, causing unavoidable and prolonged disturbance to the nesting adults.
\end{abstract}

Key words: disturbance, fish farms, Lagoon of Venice, nesting success, Po Delta, UAV

Riassunto - Utilizzo di un drone per lo studio della selezione dell'habitat di nidificazione e del successo riproduttivo in due colonie di Sterna zampenere Gelochelidon nilotica in siti di difficile accesso.

L'uso dei droni nello studio della biologia riproduttiva degli uccelli acquatici ha ricevuto una notevole attenzione negli ultimi anni, ma pochissimi studi sono stati eseguiti nel Mediterraneo. Abbiamo indagato la selezione dell'habitat e il successo riproduttivo della sterna zampenere Gelochelidon nilotica in due colonie poste all'interno di valli da pesca nel Nord Adriatico, utilizzando un piccolo drone. Entrambe le colonie erano situate su isolotti circondati da acque molto basse e con fondali limo-argillosi, quindi difficili da raggiungere. Rispetto alla disponibilità, la sterna zampenere ha selezionato aree poste più in alto sopra il livello dell'acqua, con una maggiore copertura vegetale, più

${ }^{1}$ SELC soc. coop., Via dell'Elettricità 3/d, 30175 Marghera (VE), Italia.

${ }^{2}$ Rialto, San Polo 571, 30125 Venice, Italia.

* Corresponding author: scarton@selc.it

(C) 2020 Francesco Scarton, Roberto G. Valle

Received: 28 August 2020

Accepted for publication: 25 October 2020

Online publication: 20 October 2021 lontano dal bordo dell'acqua e più frequentemente al centro degli isolotti. Da 147 dei 178 nidi (covata media + SD: 2,61 + 0,58 uova) sono sgusciati 383 pulcini $(82,5 \%)$, con grandi differenze tra le due colonie. Il successo di schiusa nelle due colonie è stato del $95,0 \%$ e $69,1 \%$; nel complesso la causa più comune di perdita di uova $(97,0 \%)$ è stata la sommersione dei nidi. La presenza del nido e del suo contenuto è stata facilmente accertata con le immagini ottenute dal drone da $30 \mathrm{~m}$ di altezza. L'uso del drone ha permesso lo studio di alcuni aspetti della biologia riproduttiva della sterna zampenere in due colonie dove il tradizionale approccio sul campo, con ricercatori che raggiungono i siti in barca, sarebbe stato molto difficile, causando inevitabili e prolungati disturbi agli adulti nidificanti.

Parole chiave: Delta del Po, disturbo, Laguna di Venezia, successo riproduttivo, valli da pesca.

\section{INTRODUCTION}

The study of several aspects of the breeding ecology of seabirds, such as population size, nesting success, habitat selection may be particularly difficult for several species, given the often rough terrain where birds make their nests. Nesting sites may be virtually inaccessible, as for instance those in marshy areas or rocky islets, and expensive airplane surveys with their inherent limitations, as limited spatial resolutions of the imagines obtained, are often made (Afán et al., 2018; Rexer-Huber et al., 2020). However, if detailed information are needed, these require higher spatial and temporal resolution, both achievable only with repeated on-ground surveys or, more recently, camera traps (Brandis et al., 2014). An even more important issue concerns the effects, direct and indirect, of the disturbance caused by researchers to the seabirds, both adults and chicks, and inherently associated to the field operations, such as counting nests or marking eggs and young (Götmark, 1992; Nisbet, 2000; Fair \& Jones, 2010). The results of many studies on the effects of researcher activity at nesting sites are ambiguous: some authors found measurable negative effects, such as reduced fledging rates, chick growth or return rates to the nesting sites the following year (Rodway, 1996; Blackmer et al., 2004; Carey, 2009; Uher-Koch et al., 2015), while other did not find any significant effects between frequently visited nests and control nests, neither on short- nor on medium-term period (Fiske et al., 2013; Kelly et al., 2015). Quite recently, a meta-analysis study showed an unexpected, positive relationship between disturbance 
and reproductive success, particularly in coastal birds nesting on the ground; this was interpreted as due to limited predator activity around nests, probably in response to fieldworker presence and activity (Ibáñez-Álamo et al., 2012).

Over the last decade, a new methodology has been proposed to count seabirds, i.e. using unmanned aerial vehicles (UAVs, or drones: Sardà-Palomera et al., 2012; Marinov et al., 2016; Rush et al., 2018; Hodgson et al., 2018; Valle \& Scarton, 2019a, 2019b; Choi et al., 2020; Mapes et al., 2020). There is a growing body of evidence suggesting that drones cause less disturbance than traditional monitoring methods (Hodgson \& Koh, 2016; Mulero-Pázmány et al., 2016; Reintsma et al., 2018, but see Valle \& Scarton, 2019a). Moreover, they are increasingly used to study the reproductive biology of waterbirds at dangerous or almost inaccessible sites, such as the enormous wetlands of the Okavango Delta (Francis et al., 2020), or some rocky islets amidst the middle of the Pacific Ocean (Inaccessible Island: McClelland et al., 2016). On a European perspective, drones have proven to be fundamental in censusing Great White Heron $\mathrm{Ar}$ dea alba nests scattered through large Polish reedbeds (Zbyryt, 2019) or in evaluating colony settlement and nesting success of Black-headed Gull Chroicocephalus ridibundus at Spanish saltmarshes (Sardà-Palomera et al., 2017).

Quite surprisingly, the use of this boosting technology seems to be still little adopted in Italy, at least judging from the scientific literature: we were able to find just one paper (Sartori \& D'Alterio, 2016) dealing with drone counts made at a large heronry in NE Italy. After that, several works have been recently published, dealing with the use of drone for studying some aspects of the breeding ecology of the European Oystercatcher Haematopus ostralegus (Valle \& Scarton, 2019a), the Common Redshank Tringa totanus (Valle \& Scarton, 2019b), the Pied Avocet Recurvirostra avosetta (Scarton \& Valle, 2020), or the disturbance caused to several waterbirds (Valle \& Scarton, 2018). Drones were also used to count heron colonies in Tuscany, Central Italy (P. Giovacchini, pers. com.); it is very likely other experiences have been made elsewhere in Italy, with results confined so far to the so-called grey literature.

The present study aims to assess the feasibility of drone assessment of habitat selection and breeding success of Gull-billed Tern Gelochelidon nilotica, hereafter GBT, nesting on sites of very low accessibility; we report also possible limitations and recommendations about the use of drones for the study of this species.

\section{STUDY AREA AND METHODS}

The fieldwork was performed throughout the breeding season 2018 in two fish farms, which are called "valli da pesca" in Italian, respectively located in the Lagoon of Venice and in the Po Delta, along the Adriatic coastline in north-eastern Italy, which spans from $45^{\circ} 28^{\prime} \mathrm{N}, 12^{\circ} 35^{\prime} \mathrm{E}$ in the North until $44^{\circ} 47^{\prime} \mathrm{N}, 12^{\circ} 23^{\prime}$ E to the South.

This $100 \mathrm{~km}$ long coastline is characterized by several shallow lagoons, from a few hundred hectares to several hundreds of square kilometers; these lagoons are scattered with hundreds of marsh islands and are bordered, along the inner side, by about thirty fish farms, each one ranging in size from 100 ha to 1,400 ha (Scarton et al., 2018; Day et al., 2019). Despite their name, most of the fish farms are currently managed almost exclusively for hunting gamebirds, ducks in particular; for this purpose, water level inside the fish farms are tightly regulated, small islands are made with sediments dredged from the adjacent channels and food is extensively provided to ducks throughout the winter. The seabird community breeding in the whole study area is one of the largest around the Mediterranean, with 20,000 pairs. Eight species of breeding gulls and terns have been recorded over the last years, including Slender-billed Gull Larus genei, Black-headed Gull Chroicocephalus ridibundus, Mediterranean Gull Larus melanocephalus, Yellow-legged Gull Larus michahellis, GBT, Sandwich Tern Thalasseus sandvicensis, Common Tern Sterna hirundo, and Little Tern Sternula albifrons; most of these species nest inside the fish farms too, often in the islets mentioned above, with populations ranging in size from a few hundred to several thousands of pairs (Scarton et al., 2018). In this large wetland complex, the GBT is a regular breeder since 2001; over the 2001-2018 years, the population ranged between 34 and 921 pairs and the trend was of strong increase, with an annual rate of $10.5 \%$ (Grussu et al., 2019).

We studied two distinct monospecific colonies, both inside fish farms:

1) the "Venice colony", in the Lagoon of Venice, consisted of 90 pairs, located on a hearth artificial islet of 0.006 ha, about $0.1 \mathrm{~m}$ above the water level and with a vegetation cover of $100 \%$ (Fig. 1);

2) the "Po colony", settled in the Po Delta, consisted of 88 pairs and was located on a hearth artificial island of $0.32 \mathrm{ha}, 0.10-0.20 \mathrm{~m}$ above the water level, without vegetation cover (Fig. 2). Both islets were built to be used as a roosting site by ducks during the hunting season (September-January), but were severely eroded after being unmanaged for many years. Both colony sites were surrounded by large and shallow waterbodies, which had a very soft, clayey bottom, that made them virtually inaccessible by terrestrial predators or a walking man. On the other side, a boat approach would be extremely slow and difficult, causing severe disturbance to the breeding birds.

In order to study the habitat selection and breeding success of GBT, we performed six weekly drone surveys at $0,1,2,3,4$ and 7 weeks from laying; we used an offthe-shelf, small drone (DJI Mavic pro), with a weight of $734 \mathrm{~g}$ and a noise level of $70.0 \mathrm{~dB}(\mathrm{~A})$. The six surveys, which were carried out up to three weeks of chick age, permit only a conservative estimate of productivity, but we chose not to fly over older chicks that would be capable of flying away in response to drone intrusion.

According to the current recommendations (Hodgson \& Koh, 2016; Valle \& Scarton, 2018), the drone was launched at approximately $150 \mathrm{~m}$ from each colony; in order to minimize disturbance to birds, the drone reached the vertical point of the colony through a lawn-mower 
flight pattern, flying $70 \mathrm{~m}$ above ground level (AGL) and was slowly lowered $(1.5 \mathrm{~m} / \mathrm{sec})$ to an altitude of $30 \mathrm{~m}$, where nest attendance was assessed, checking whether incubating birds were present.

Then, the drone was slowly driven to an altitude of $3 \mathrm{~m}$ AGL, which allows clutches, eggs and chicks to be clearly detected upon post-processing (Fig. 1 and Fig. 2) and it slowly flew over the colony at a speed of $1.5 \mathrm{~km} / \mathrm{h}$. During each drone flight, a researcher observed the colony from afar to exclude possible predation of unattended clutches and/or chicks.

In the post-processing phase, individual nests were assigned a number and counts of clutches, eggs per clutch, hatchlings and older chicks were performed by two observers using the recorded videos on a personal computer using the free software GIMP for imagine processing (release 2.10; https://www.gimp.org). Nests were ascribed to one of the following categories: 1) successful, if a) a recently hatched chick was found in the nest or nearby, b) date of egg disappearance matched expected hatching date and no sign of predation was found, or 2) unsuccessful, when a) unattended, b) flooded, c)

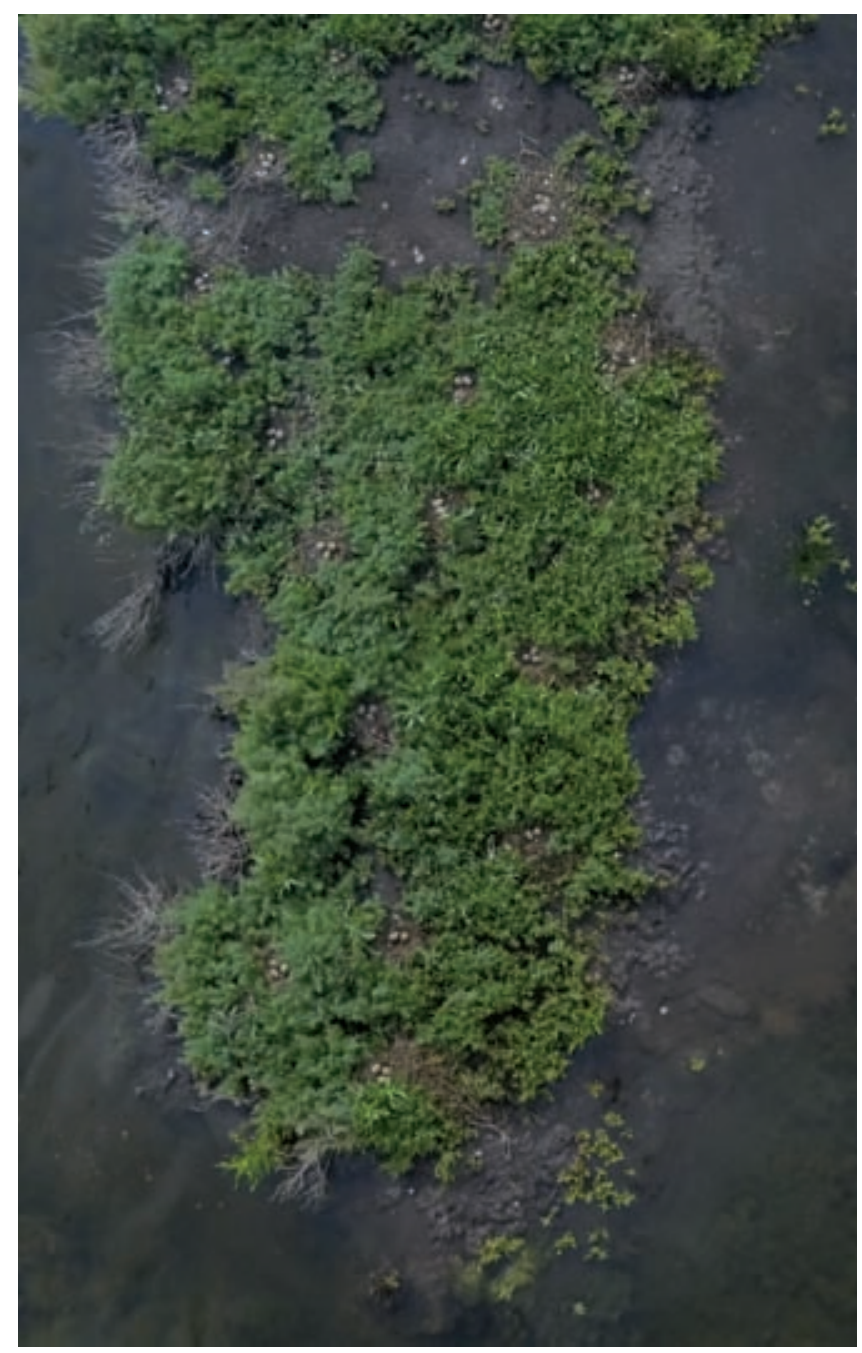

Fig. 1 - Nest distribution in a colony of Gull-billed Terns in the Lagoon of Venice in 2018. / Distribuzione dei nidi in una colonia di sterne zampenere nella Laguna di Venezia nel 2018. predated, or d) disappeared, when egg disappearance was prior to expected hatching date according to Grussu et al. (2019).

Habitat choice was investigated superimposing a grid of $1 \times 1-\mathrm{m}$ quadrates on the drone imagery of the colony sites using the free software QGIS (release 3.12.1; www.qgis.org), stitching images together with ICE (Microsoft's Image Composite Editor, release 2.0; https:// www.microsoft.com). We characterized each quadrate for the presence-absence and number of nests and for the following biotic and abiotic parameters: 1) \% of the quadrate covered by vegetation, bare mud, water surface both inside the islets and surrounding the islets; 2) \% cover by the dominant plant species; 3 ) height of ground above the water level, visually estimated in two categories $(<30 \mathrm{~cm}$ and $>30 \mathrm{~cm}$ ) according to field observations made in the days before egg laying, since water level inside the fish farms may change abruptly during a breeding season; 4) location, classified as "central" (the quadrate was separated from the water edge by at least another quadrate) or "peripheral" (the quadrate was at the water edge).

Nest site selection was characterized using QGIS and images, recording: 1) substrate type (mud, vegetation, bivalve shells, etc.); 2) elevation above water level (AWL), visually dichotomized in low $(<30 \mathrm{~cm})$ and high $(>30$ $\mathrm{cm})$. The high location could result either from placing nest on bare ground in areas with elevation $>30 \mathrm{~cm}$ or by building nest on vegetation taller than $30 \mathrm{~cm} ; 3$ ) presence of vegetation circling the nest for the whole perimeter; 4) distance from the closest body of water, either inside or outside the colony site; 5) distance from the nearest neighbor nest.

The amount of disturbance during each flight was estimated from: 1) the mean duration of permanence of the drone over the colony; 2) the time spent away from nests by incubating birds, until the last breeding bird went back to the nest; 3 ) the distance walked/swum by chicks.

Categorical data are presented as numbers (percent) and continuous data as means $+1 \mathrm{SD}$. Variables not normally distributed $($ Kolmogorov-Smirnov test; $\mathrm{P}<0.001$ ) were square-root or arc-sin-square-root transformed as necessary to meet assumptions of normality for parametric tests. All tests were two-tailed, and $P<0.05$ was considered significant. Difference in count data (elevation above water level and location of nests) were tested by means of a $\chi^{2}$ test. Differences in mean number of fledged young per nest between sites were analysed by means of paired $t$-tests (Sokal \& Rohlf, 1981).

We investigated the relationships of the biotic and abiotic variables of marsh islands with GBT presenceabsence by means of logistic regression (Sokal \& Rohlf, 1981). We conducted correlation analyses (Spearman's test) to reduce collinearity and the number of variables used in multivariate analyses (Green, 1993); we retained the variable perceived as more biologically important among two or more of strongly inter-correlated variables $(r>0.60)$, since they may be considered as estimates of a single underlying factor. We compared survival functions using Cox proportional hazards model, a semiparametric method (Cox, 1972); analyses were performed using SPSS software for Mac, release 20.0 (SPSS, Inc., Chicago, IL). 


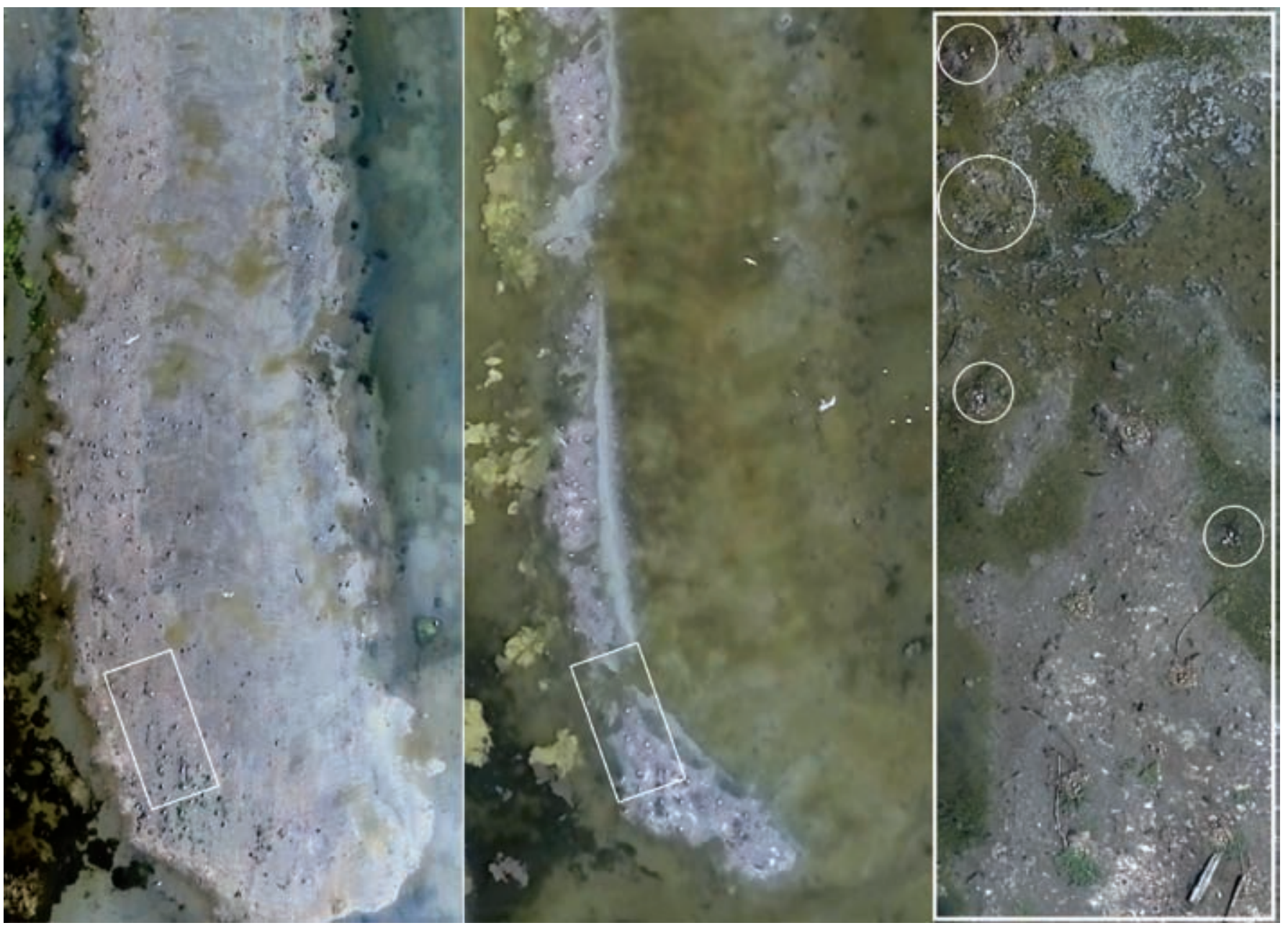

Fig. 2 - Left panel: baseline nest distribution in a colony of Gull-billed Terns in the Po Delta in 2018. Central panel: nest distribution after flooding. Right panel: magnification of a plot with nests (white box) after flooding. White circles: flooded nests. / Pannello di sinistra: distribuzione dei nidi in una colonia di sterne zampenere nel Delta del Po nel 2018. Pannello centrale: distribuzione dei nidi dopo l'allagamento. Riquadro destro: ingrandimento della precedente (riquadro bianco). Cerchi bianchi: nidi allagati.

\section{RESULTS}

\section{Habitat selection}

Habitat use differed from a random pattern, as apparent by the distribution of nests on drone imagery (Fig. 1 and Fig. 2). Compared with availability, GBT positively selected quadrates higher above the water level, with a higher vegetation cover, which lay farther from the water edge, contain less water, and more frequently located in the center of the island (Tab. 1). Both elevation above the water level and vegetation cover entered the stepwise binary logistic regression for GBT presence prediction (Tab. 2). A ROC curve (not illustrated) was traced to estimate the predictive power of the model $(\mathrm{AUC} \pm \mathrm{SE}=0.826 \pm 0.024 ; \mathrm{CI}=0.779-0.873)$.

\section{Breeding success}

One hundred and forty-seven out of 178 clutches (for overall 464 eggs; $2.61 \pm 0.58$; range $1-4$ ) hatched 383 chicks $(82.5 \% ; 2.15 \pm 1.09$ chicks per nest), with large differences between the two colonies. Hatching success ranged from $95.0 \%$ in the Venice colony $(2.54 \pm 0.66$ hatched chicks per nest) to $69.1 \%$ in the Po colony ( 1.80 \pm 1.28 hatched chicks per nest: $t$-test $=-5.2$; $\mathrm{P}<0.001$ ). Overall, from 28 nests (15.7\%) did not hatch any chick and 17 more nests had a partial loss of one or two eggs, thus overall 80 eggs $(17.5 \%)$ were lost (Tab. 3$)$.

The most common cause of egg loss was flooding $(97 \%)$. Flooded nests were easily classified by drone surveys, since they appeared heavily damaged and eggs were very frequently washed away from the cups (Fig. 2). As an aside, we mention that among 52 flooded nests, in the 19 which were circled for at least $270^{\circ}$ by vegetation higher than the cup, only $13(22 \%)$ had eggs washed away in comparison with $24 \%$ of the remainder $\left(\mathrm{Chi}^{2}=22.0 ; \mathrm{P}<0.001\right)$. Eggs retained in flooded nests were then successfully brooded to hatching. No eggs were predated, but three eggs disappeared from a "high" nest safe from flooding. Cox multivariate regression confirmed the superiority of both the elevation above the water level $(\mathrm{HR}=7.869, \mathrm{P}=0.005)$ and to a lesser extent the distance from the water edge (HR $=1.014, \mathrm{P}=0.001)$ as prognostic indexes of egg survival. Fledging success ranged from 0.56 young fledged per pair for clutches in the Po colony to 1.40 in the Venice colony. 
Tab. 1 - Drone-derived, imagery-based assessment of nest site selection of Gull-billed Terns nesting in two colonies. Environmental variables were measured at $1-\mathrm{m}^{2}$ quadrats occupied or not by the species. / Valutazione (derivata da droni e basata su immagini) della selezione del sito di nidificazione di sterne zampenere nidificanti in due colonie. Le variabili ambientali sono state misurate su quadrati di $1 \mathrm{~m}^{2}$ occupati o meno dalla specie.

${ }^{a} t$ test carried out on the variable square root or arc-sin square root transformed. / ${ }^{\text {a }} t$ test effettuato su dati normalizzati mediante radice quadrata variabile o radice quadrata arco-sin trasformata.

${ }^{\mathrm{b}}$ Difference tested by means of a $\chi^{2}$ test on the count data. / ${ }^{\mathrm{b}}$ Differenza verificata mediante test $\chi^{2}$.

\begin{tabular}{|c|c|c|c|c|}
\hline Parameter & All & Occupied & Non occupied & $\mathrm{P}$ \\
\hline Venice colony $(\mathrm{N}=76)$ & $\mathrm{N}=76$ & $\mathrm{~N}=45$ & $\mathrm{~N}=21$ & \\
\hline Vegetation cover $(\%)$ & $58 \pm 30$ & $71 \pm 25$ & $30 \pm 20$ & $<0.001$ \\
\hline $\operatorname{Mud}(\%)^{a}$ & $11 \pm 13$ & $11 \pm 14$ & $13 \pm 11$ & 0.368 \\
\hline External water $(\%)^{a}$ & $30 \pm 27$ & $18 \pm 20$ & $57 \pm 21$ & $<0.001$ \\
\hline Internal water $(\%)^{a}$ & $2 \pm 11$ & $3 \pm 13$ & $0 \pm 0$ & 0.272 \\
\hline $\begin{array}{l}\text { Ground elevation above water level (n/\%) } \\
-<30 \mathrm{~cm} \\
->30 \mathrm{~cm}\end{array}$ & $\begin{array}{c}6 \\
60\end{array}$ & $\begin{array}{c}1 / 17 \\
44 / 73\end{array}$ & $\begin{array}{c}5 / 83 \\
16 / 27\end{array}$ & 0.011 \\
\hline $\begin{array}{l}\text { Location }(\mathrm{n} / \%) \\
\text { - peripheral } \\
\text { - central }\end{array}$ & $\begin{array}{c}8 \\
58 \\
\end{array}$ & $\begin{array}{l}8 / 100 \\
37 / 64\end{array}$ & $\begin{array}{c}0 / 0 \\
21 / 36\end{array}$ & 0.041 \\
\hline Po colony $(\mathrm{N}=816)$ & $\mathrm{N}=816$ & $\mathrm{~N}=83$ & $\mathrm{~N}=733$ & \\
\hline Vegetation cover $(\%)^{a}$ & $0.3 \pm 2.5$ & $1.7 \pm 6.0$ & $0.1 \pm 1.6$ & $<0.001$ \\
\hline $\operatorname{Mud}(\%)^{a}$ & $89 \pm 27$ & $99 \pm 3$ & $88 \pm 28$ & $<0.001$ \\
\hline External water $(\%)^{\text {a }}$ & $3.6 \pm 14.4$ & $0.4 \pm 3.3$ & $4.0 \pm 15.1$ & 0.020 \\
\hline Internal water (\%) & $7 \pm 23$ & $0 \pm 0$ & $8 \pm 25$ & 0.002 \\
\hline $\begin{array}{l}\text { Elevation above water level }(\mathrm{n} / \%) \\
-<30 \mathrm{~cm} \\
->30 \mathrm{~cm}\end{array}$ & $\begin{array}{l}690 \\
126\end{array}$ & $\begin{array}{c}33 / 5 \\
50 / 40\end{array}$ & $\begin{array}{c}657 / 95 \\
76 / 60\end{array}$ & $<0.001$ \\
\hline $\begin{array}{l}\text { Location }(\mathrm{n} / \%) \\
\text { - peripheral } \\
\text { - central }\end{array}$ & $\begin{array}{c}741 \\
75\end{array}$ & $\begin{array}{c}81 / 11 \\
2 / 3\end{array}$ & $\begin{array}{c}660 / 89 \\
73 / 97\end{array}$ & 0.025 \\
\hline
\end{tabular}

Tab. 2 - Nest site selection of Gull-billed Terns nesting in two colonies (pooled data) according to binary logistic regression ( $89 \%$ of correctly reclassified cases). / Selezione del sito di nidificazione di Sterne zampenere nidificanti in due colonie (dati aggregati) in base alla regressione logistica binaria ( $89 \%$ dei casi correttamente riclassificati).

${ }^{a}$ Environmental variables were measured at $1-\mathrm{m}^{2}$ quadrats occupied or not by the species. / Le variabili ambientali sono state misurate su quadrati di $1 \mathrm{~m}^{2}$ occupati o meno dalla specie.

\begin{tabular}{|l|c|c|c|}
\hline Variable & Parameter estimate \pm SE & df & $P$ \\
\hline Ground elevation above water level $>30 \mathrm{~cm}$ (yes vs. no) & $2.331 \pm 0.260$ & 1 & $<0.001$ \\
\hline Vegetation cover (\%) & $0.050 \pm 0.025$ & 1 & 0.045 \\
\hline${\text { Internal water }(\%)^{\text {a }}}^{\text {External water }(\%)^{\text {a }}}$ & $-0.039 \pm 0.028$ & 1 & 0.169 \\
\hline Mud (\%) ${ }^{\text {a }}$ & $-0.036 \pm 0.032$ & 1 & 0.267 \\
\hline
\end{tabular}


Tab. 3 - Breeding success of Gull-billed Terns nesting in two colonies, data pooled together, in relation to habitat selection. Environmental variables were measured on drone-derived imagery at $0.5-\mathrm{m}$ circles around nests. / Successo riproduttivo di sterne zampenere nidificanti in due colonie, dati aggregati, in relazione alla selezione dell'habitat. Le variabili ambientali sono state misurate su immagini derivate da droni su cerchi di $0,5 \mathrm{~m}$ attorno ai nidi.

${ }^{a} t$ test carried out on the variable square root or arc-sin square root transformed. / ${ }^{\text {a }} t$ test effettuato su dati normalizzati mediante radice quadrata o radice quadrata arcoseno trasformata..

${ }^{\mathrm{b}}$ Difference tested by means of a $\chi^{2}$ test on the count data. / Differenza verificata mediante test $\chi^{2}$.

\begin{tabular}{|l|c|c|c|c|}
\hline Parameter & All & Successful nests $(\mathrm{N}=148)$ & Failed nests $(\mathrm{N}=30)$ & $P$ \\
\hline Distance from the water edge $(\mathrm{m})^{\mathrm{a}}$ & $0.81 \pm 0.63$ & $0.75 \pm 0.68$ & $1.07 \pm 0.35$ & $<0.002$ \\
\hline${\text { Nearest neighbour distance }(\mathrm{m})^{\mathrm{a}}}^{\mathrm{a}}$ & $1.04 \pm 0.50$ & $1.26 \pm 0.40$ & $0.58 \pm 0.33$ & 0.621 \\
\hline${\text { Vegetation cover }(\%)^{\mathrm{a}}}^{\mathrm{a}}$ & $52.0 \pm 49.2$ & $63 \pm 48$ & $6 \pm 25$ & $<0.001$ \\
\hline Elevation above water level (n/\%) ${ }^{\mathrm{b}}$ & & & & $<0.001$ \\
\hline$<30 \mathrm{~cm}$ & 113 & $85 / 75$ & $28 / 25$ & \\
\hline$>30 \mathrm{~cm}$ & 65 & $63 / 97$ & $2 / 3$ & \\
\hline
\end{tabular}

\section{Drone effectiveness and disturbance}

In the Po colony, where nests were in a bare area, drone imagery clearly visualized all present clutches, eggs and chicks (Fig. 1 and Fig. 2). In the Venice colony, in vegetated areas early in the season nests were clearly visible, due to low vegetation height and cover; then, the latter rapidly grew, partially hiding some nests (Fig. 1). Anyway, nest attendance could always be ascertained by $30-\mathrm{m}$ AGL drone-derived imagery, which could easily record incubating birds sitting on nests (Fig. 1; Fig. 2). Likewise, while chicks were clearly visible in bare areas, they might easily hide within vegetation in response to low elevation AGL drone intrusions in the colony with high vegetation cover (Fig. 1).

Neither nest desertions, nor clutch/chick predations were observed during drone surveys. Time spent far from nests by alarming birds for 12 surveys was very short (105 $\pm 67 \mathrm{sec}$ ) and roughly coincided with the mean duration of permanence of the drone over the colony, in view of the short flight initiation distances of the species for the drone $(12 \pm 9 \mathrm{~m}, \mathrm{~N}=12)$. The distance walked/swum from the colony site by chicks in response to drone intrusion was very short: $0.6 \pm 0.8 \mathrm{~m}, \mathrm{~N}=175$. The time taken to complete the whole surveys (12 visits) was 23 min for drone inspections of the colonies and $27 \mathrm{~min}$ of additional drone flight time, but 126 more min were needed for post-processing work for overall $176 \mathrm{~min}$.

\section{DISCUSSION AND CONCLUSIONS}

The use of a drone allowed the study of habitat selection, nest site selection and reproductive success of GBT in two breeding sites where the traditional approach, i.e. researchers reaching the islets by boat and then collecting data in the field, would have been very difficult, causing unavoidable disturbance to the nesting adults. As known from other studies (Fasola \& Canova, 1991 and 1992; Barati et al., 2012; Wu et al., 2020) the GBT did select some specific environmental features, preferring habitat patches which could reduce (due to their position and elevation) the possibility of nests being washed away. Among the possible causes of nests failures, previous studies found predation, flooding and human disturbance (see review in Gochfeld et al., 2017); nevertheless, recent studies made by Windhoffer et al. (2017) at barrier islands and Grussu et al. (2019) in man-regulated habitats found flooding was the main cause of breeding failure. In the fish farms, rapid increase in the water levels sufficient to flood the islets are generally due to strong rainfalls, as we observed several times during concomitant studies. GBT eggs and/or chicks may be predated by both mammalian and aerial predators (Eyler et al., 1999; Molina \& Erwin, 2006; Gochfeld et al., 2017); at our study sites, the possible terrestrial predators, such as the Red Fox Vulpes vulpes, were most likely deterred by the very shallow water and soft bottoms surrounding the islets. It has been documented several times that the occurrence of this predator may significantly impact the nesting success of waterbirds (see for a recent review Alessandria \& Carpegna, 2019); thus the selection of small islets, quite far from banks and levees and completely surrounded by water, seems to be of primary importance for the settlements of GBT colonies. This evidence should be well acknowledged when planning management actions for the conservation of this species.

On the other hand, possible aerial predators in our area included Yellow-legged Gull, Marsh Harrier Circus aeruginous and Carrion Crow Corvus corone, but again we did not observe any event of predation. Elsewhere, aerial predation of GBT clutches due to both diurnal and nocturnal raptors has been documented (Eyler et al., 1999; Windhoffer et al., 2017).

Overall, the hatching success at our two study sites, due to both the absence of predation and the limited impact of flooding events, was high $(82.5 \%)$, similar or higher than values reported by other authors (Eyler et al., 1999; Barati et al., 2012). Fledging success was different between our two study sites (0.56 vs. 1.40 young/pair); and in addition considering the different hatching success 
$(69.1 \%$ vs. $95 \%)$, it is clear the Venice lagoon colony was superior to the Po Delta colony, in terms of productivity. We can only speculate about the possible causes, such as a better food availability in the surrounding of the colony sites and the different age of the breeding adults. On the other hand, an underestimation could not be ruled out due to a possible displacement of chicks towards dikes and islets, which were abundant in the surroundings of the Po colony.

Despite the above-mentioned strengths of our study, we declare some limitations, which are inherent to studies investigating waterbirds by drone imagery. First, we lack a comparison to ground data as a control of our results (Chabot et al., 2014), so that further comparative studied are needed to assess the accuracy and precision of the drone approach. A second limitation resides in a possible underestimation of fledging success, since fledglings could have hidden within the surrounding vegetation before they were detected by drone in the Venice colony (Grussu et al., 2019). Though this is improbable, due to the high figure of fledging success found in this colony and the limited available space, underestimation could be a matter of concern in large, highly vegetated sites. Anyway, higher altitude flights ( $>5 \mathrm{~m}$ AGL) could solve the problem avoiding chick hiding in response to the approaching drone (Brisson-Curadeau et al., 2017). A final limitation concerns the inclusion of small, singlespecies colonies in our study. The possibility to broaden drone use for habitat selection and breeding success assessment in large, multi-specific seabird colonies, where expertise is strongly required for the differential diagnosis of clutches of different species, needs further confirmation studies.

Our results indicate that drone flights may be successfully used to count nests of GBT and to estimate the bird's reproductive success. If the use of drones to census nesting seabirds is already well established (Hodgson \& Koh, 2016; Hodgson et al., 2016; BrissonCuradeau et al., 2017; Barr et al., 2018; Rush et al., 2018; Valle \& Scarton, 2019a and 2019b), far less is known about the possibility of using them for estimation of reproductive success. As far as we know, only four studies have used drones to collect data on reproductive success in waterbirds: Brisson-Curadeau et al. (2017) for two gull species, Sardà-Palomera et al. (2017) for the Blackheaded Gull, Pöysä et al. (2018) for three duck species and Scarton \& Valle (2020) for Pied Avocet.

The findings of our study indicate that drone flights caused very little disturbance to breeding adults and chicks, as it appears from the short times in which adults abandoned their clutches, the absence of predations in the same occasions and the short distances made by chicks walking or swimming away. We would like to underline that we are not claiming drone-derived imagery can replace the traditional ground counts to assess habitat selection and productivity of seabirds. Drone surveys requires an integrated approach, including on-ground supportive data to be interpreted in an unbiased manner (Callaghan et al., 2018). Nevertheless, a drone-based approach is a useful tool for the assessment of habitat selec- tion and breeding success of Gull-billed Terns, nesting in small, single-species colonies and may represent an optimal alternative method for field researchers at lowaccessibility sites.

\section{Acknowledgments}

We are grateful to Rosalino Garbi, Alberto Palumbo e Gianluca Zappaterra for their valuable help in the field. P. Giovacchini kindly supplied us unpublished information, and an anonymous referee improved the manuscript. This study was self-financed.

\section{REFERENCES}

Afán I., Máñez M. \& Díaz-Delgado R., 2018 - Drone Monitoring of Breeding Waterbird Populations: The Case of the Glossy Ibis. Drones, 2 (4): 42.

Alessandria G. \& Carpegna F., 2019 - Attività trofica di Vulpes vulpes in una zona umida: quali effetti sulla biologia riproduttiva di Ardea purpurea? Research in Ornithology, 89: 27-32.

Barati A., Etezadifarb F. \& Esfandabad B. S., 2012 - Nest-site selection and hatching success at a mixed-species colony of Black-winged Stilts Himantopus himantopus and Gull-billed Tern Gelochelidon nilotica. Avian Biology Research, 5: 142-146.

Barr J. R., Green M. C., DeMaso S. J. \& Hardy T. B., 2018 - Detectability and visibility biases associated with using a consumer-grade unmanned aircraft to survey nesting colonial waterbirds. Journal of Field Ornithology, 89: 242-257.

Blackmer A. L., Ackerman J. T. \& Nevitt G. A., 2004 - Effects of investigator disturbance on hatching success and nest-site fidelity in a long-lived seabird, Leach's storm-petrel. Biological Conservation, 116: 141-148.

Brandis K. J., Koeltzow N., Ryall S. \& Ramp D., 2014 - Assessing the use of camera traps to measure reproductive success in Strawnecked Ibis breeding colonies. Australian Field Ornithology, 31: 99-106.

Brisson-Curadeau É., Bird D., Burke C., Fifield D. A., Pace P., Sherley R. B. \& Elliot K. H., 2017 -Seabird species vary in behavioural response to drone census. Scientific Reports, 7: 17884.

Callaghan C. T., Brandis K. J., Lyons M. B., Ryall S. \& Kingsford R. T., 2018 - A comment on the limitations of UAVS in wildlife research - the example of colonial nesting waterbirds. Journal of Avian Biology, 49: e01825.

Carey M. J., 2009 - The effects of investigator disturbance on Procellariiform seabirds: a review. New Zealand Journal of Zoology, 36: 367-377.

Chabot D., Carignan V. \& Bird D. M., 2014 - Measuring Habitat Quality for Least Bitterns in a Created Wetland with Use of a Small Unmanned Aircraft. Wetlands, 34: 527-533.

Choi H. I., Nam H. K. \& Yoon J., 2020 - Testing the potential of lightweight drones as a tool for monitoring the status of colonially breeding Saunders's gulls (Saundersilarus saundersi). The Korean Journal of Ornithology, 27: 10-16.

Cox D. R., 1972 - Regression Models and Life-Tables. Journal of the Royal Statistical Society, Series B; 34: 187-220.

Day J. W., Ibáñez C., Pont D. \& Scarton F., 2019 - Status and Sustainability of Mediterranean Deltas: The Case of the Ebro, Rhône, and Po Deltas and Venice Lagoon. In: Coasts and Estuaries. Wolanski E., Day J. W., Elliott M., Ramachandran R. (eds.). Elsevier: 237249.

Eyler T. B., Erwin E. R., Stotts D. B. \& Hatfield J. S., 1999 - Aspects of Hatching Success and Chick Survival in Gull-billed Terns in Coastal Virginia. Waterbirds, 22: 54-59.

Fair J. M. \& Jones J. (eds.), 2010 - Guidelines to the use of wild birds in research. Ornithological Council, Washington, D.C.

Fasola M. \& Canova L., 1991 - Colony site selection by eight species of gulls and terns breeding in the "Valli di Comacchio" (Italy). Bollettino di zoologia, 58: 261-266. 
Fasola M. \& Canova L., 1992 - Nest Habitat Selection by Eight Syntopic Species of Mediterranean Gulls and Terns. Colonial Waterbirds, 15: 169-178.

Fiske J. A., Gannon D. \& Newman A. E., 2013 - Effects of repeated investigator handling of Leach's Storm-Petrel chicks on growth rates and the acute stress response. Journal of Field Ornithology, 84: 425-432.

Francis R. J., Lyons M. B., Kingsford R. T. \& Brandis K. J., 2020 Counting Mixed Breeding Aggregations of Animal Species Using Drones: Lessons from Waterbirds on Semi-Automation. Remote Sensing, 12: 1185.

Gochfeld M., Burger J., Kirwan G. M. \& Garcia E., 2017 - Common Gull-billed Tern (Gelochelidon nilotica). In: Handbook of the Birds of the World Alive. del Hoyo J., Elliott A., Sargatal J., Christie D. A. \& de Juana E. (eds.). Lynx Edicions, Barcelona. <http://www. hbw.com/node/54012> (retrieved on 7 October 2017).

Götmark F., 1992 - The effects of investigator disturbance on nesting birds. In: Current Ornithology. Power D. M. (ed.). Springer, 9: 63-104.

Green R., 1993 - Nomograms for estimating the stage of incubation of wader eggs in the field. Wader Study Group Bullettin, 69: 107110.

Grussu M., Scarton F., Verza E. \& Valle R. G., 2019 - Long term trends and breeding parameters of Gull-billed Tern Gelochelidon nilotica in three Italian coastal sites. Research in Ornithology, 89. <https:// doi.org/10.4081/rio.2019.438>

Hodgson J. C., Baylis S., Mott R., Herrod A. \& Clarke R. H., 2016 Precision wildlife monitoring using unmanned aerial vehicles. Scientific Reports, 6: 22574.

Hodgson J. C. \& Koh L. P., 2016 - Best practice for minimising unmanned aerial vehicle disturbance to wildlife in biological field research. Current Biology, 26: 404-405.

Hodgson J. C., Mott R., Baylis S. M., Pham T. T., Wotherspoon S., Kilpatrick A. D., Segaran R. R., Reid I., Terauds A. \& Koh L. P., 2018 - Drones count wildlife more accurately and precisely than humans. Methods in Ecology and Evolution, 9: 1-8.

Ibáñez-Álamo J. D., Sanllorente O. \& Soler M., 2012 -The impact of researcher disturbance on nest predation rates: a meta analysis. Ibis, 154: 5-14.

Kelly K. G., Diamond A. W., Holberton R. L. \& Bowser A. K., 2015 Researcher handling of incubating Atlantic Puffins Fratercula arctica has no effect on reproductive success. Marine Ornithology, 43: 77-82.

Mapes K. L., Pricope N. G., Baxley J. B., Schaale L. E. \& Danner R. M., 2020 - Thermal Imaging of Beach-Nesting Bird Habitat with Unmanned Aerial Vehicles: Considerations for Reducing Disturbance and Enhanced Image Accuracy. Drones, 4: 12.

Marinov M., Pogan T., Doroșencu A., Nichersu I., Alexe V., Trifanov C. \& Kiss J., 2016 - Monitoring the Great White Pelican (Pelecanus onocrotalus Linnaeus, 1758) breeding population using drones in 2016 - the Danube Delta (Romania). Scientific Annals of the Danube Delta Institute, 22: 41-52.

McClelland G. T., Bond A. L., Sardana A. \& Glass T., 2016 - Rapid population estimate of a surface-nesting seabird on a remote island using a low-cost unmanned aerial vehicle. Marine Ornithology, 44: 215-220.

Molina K. \& Erwin R. E., 2006 - The Distribution and Conservation Status of the Gull-billed Tern (Gelochelidon nilotica) in North America. Waterbirds, 29: 271-295.

Mulero-Pázmány M., Jenni-Eiermann S., Strebel N., Sattler T., Negro J. J. \& Tablado Z., 2017 - Unmanned aircraft systems as a new source of disturbance for wildlife: a systematic review. PloS one, 12 (6): $\mathrm{e} 0178448$.

Nisbet I. C. T., 2000 - Disturbance, Habituation, and Management of Waterbird Colonies. Waterbirds, 23: 312-332.

Pöysä H., Kotilainen J., Väänänen V.-M. \& Kunnasranta M., 2018 Estimating production in ducks: a comparison between ground surveys and unmanned aircraft surveys. European Journal of Wildlife Research, 64: 74. <https://doi.org/10.1007/s10344-0181238-2>

Reintsma K. M., McGowan P. C., Callahan C., Collier T., Gray D., Sullivan J. D. \& Prosser D. J., 2018 - Preliminary Evaluation of
Behavioral Response of Nesting Waterbirds to Small Unmanned Aircraft Flight. Waterbirds, 41: 326-332.

Rexer-Huber K., Walker K. J., Elliott G. P., Baker G. B., Debski I., Jensz K., Sagar P. M., Thompson D. R. \& Parker G. C., 2020 Population trends of light-mantled sooty albatross (Phoebetria palpebrata) at Adams Island and trial of ground, boat, and aerial methods for population estimates. Notornis, 67: 341-355.

Rodway M. S., Montevecchi W. A. \& Chardine J. W., 1996 - Effects of investigator disturbance on breeding success of Atlantic Puffins Fratercula arctica. Biological Conservation, 76 (3): 311-319.

Rush G. P., Clarke L. E., Stone M. \& Wood M. J., 2018 - Can drones count gulls? Minimal disturbance and semiautomated image processing with an unmanned aerial vehicle for colony-nesting seabirds. Ecology and Evolution, 8: 12322-12334.

Sardà-Palomera F., Bota G., Padilla N., Brotons L. \& Sardà F., 2017 - Unmanned aircraft systems to unravel spatial and temporal factors affecting dynamics of colony formation and nesting success in birds. Journal of Avian Biology, 48: 1273-1280.

Sardà-Palomera F., Bota G., Viñolo C., Pallarés O., Sazatornil V., Brotons L., Gomáriz S. \& Sardà F., 2012 - Fine-scale bird monitoring from light unmanned aircraft systems. Ibis, 154: 177-183.

Sartori A. \& D'Alterio S., 2016 - Una nuova garzaia nel SIC/ZPS Ex cave di via Villetta di Salzano-Venezia. Lavori Società Veneta di Scienze Naturali, 41: 27-32.

Scarton F. \& Valle R., 2020 - Could we assess the hatching success of Pied Avocets (Recurvirostra avosetta) by drone monitoring? A pilot study. Lavori Società Veneta di Scienze Naturali, 45: 139-142.

Scarton F., Verza E., Guzzon C., Utmar P., Sgorlon G. \& Valle R. G., 2018 - Laro-limicoli (Charadriiformes) nidificanti nel litorale nord Adriatico (Veneto e Friuli Venezia Giulia) nel periodo 2008-2014: consistenza, trend e problematiche di conservazione. RIO. Research in Ornithology, 88: 33-41.

Sokal R. R. \& Rohlf F. J., 1981 - Biometry. W. H. Freeman, New York, U.S.A.

Uher-Koch B. D., Schmutz J. A. \& Wright K. G., 2015 - Nest visits and capture events affect breeding success of Yellow-billed and Pacific loons. The Condor: Ornithological Applications, 117: 121-129.

Valle R. G. \& Scarton F., 2018 - Uso dei droni nel censimento degli uccelli acquatici nidificanti nel nord Adriatico. Bollettino del Museo di Storia Naturale di Venezia, 69: 69-75.

Valle R. G., \& Scarton F., 2019a - Effectiveness, efficiency, and safety of censusing Eurasian Oystercatchers Haematopus ostralegus by unmanned aircraft. Marine Ornithology, 47: 87-93.

Valle R. G. \& Scarton F., 2019b - Drones improve effectiveness and reduce disturbance of censusing Common Redshanks Tringa totanus breeding on salt marshes. Ardea, 107: 275-282.

Windhoffer E. D., Owen T. M., Liechty J. S., Minor A. K., Curtiss D. K., Nepshinsky M. \& Pierce A. R., 2017 - Variability in GullBilled Tern (Gelochelidon nilotica) Breeding Parameters at the Isles Dernieres Barrier Islands Refuge, Louisiana, USA. Waterbirds, 40 (4): 390-396.

Wu F., Lei W., Lloyd H. \& Zhang Z., 2020 - Predictors of Gull-billed tern (Gelochelidon nilotica) nest survival in artificial coastal saltpans, Bohai Bay, China. PeerJ 8: e10054 <http://doi.org/10.7717/ peerj.10054>

Zbyryt A., 2019 - Numbers and distribution of breeding population of the Great Egret Ardea alba in Poland. Ornis Polonica, 60: 235244. 